\title{
Waqf Blockchain Untuk Pengadaan Alat Kesehatan Penanganan Covid-19: Studi Konseptual
}

\author{
Risanda A. Budiantoro, ${ }^{1}$ Masitha Fahmi Wardhani, ${ }^{2}$ \\ Foza Hadyu Hasanatina, ${ }^{3}$ Febrianur I. F. S. Putra ${ }^{4}$ \\ ${ }^{1,2,3,4}$ Fakultas Ekonomi dan Bisnis, Universitas Dian Nuswantoro, Semarang \\ Email.risanda.abe@gmail.com
}

\begin{abstract}
: The research aims to develop a scheme of waqf fund management based on the blockchain system. This system is used for the procurement of personal protective equipment as an effort to prevent the Covid-19 pandemic in Indonesia. The approach method used qualitative research, based on the basis of consideration of data and facts related to the spread of pandemic Covid-19 requires in-depth analysis. The renewal of the schemes and instruments of the waqf fund with blockchain endowments that can be applied in specific social projects is an important added value. The results of this research are the optimization of waqf funds, which starts from the process of collecting, managing, developing and distributing waqf funds for specific social activities that can be targeted. The target of this research is the transparency of the management of waqf funds can be better so that sharia-based financial instruments can contribute greatly to the handling of Covid-19.
\end{abstract}

\section{Keywords : Covid-19, Blockchain Platform, Waqf Funds}

\section{Latar Belakang}

Pandemi Covid-19 yang sedang berlangsung sejak Desember 2019 terus semakin meluas, termasuk di Indonesia. Menurut Worldometers (2020), hingga per 12 Oktober 2020 jumlah suspek dari pandemi Covid-19 ini mencapai 37.754.464 jiwa, dimana death rate-nya mencapai 1.081 .500 kasus atau 2,86 persen sedangkan recovery rate-nya sebesar 28.361.239 kasus atau 75,12 persen. Angka terus terus mengalami peningkatan sejak 31 Desember 2019 yang menunjukkan kasus pertama di kota Wuhan, Provinsi Hubei, China. Hal yang perlu diperhatikan ketika suatu kasus sedang mewabah yaitu ketersediaan pelatan sanitasi diri maupun alat pelindung diri bagi tenaga medis yang jumlahnya semakin terbatas. Sebagai bentuk kontribusinya beberapa platform crowdfunding mulai melakukan kegiatan donasi dan penggalangan dana dengan tujuan penanganan Covid-19 ini.

Dalam momentum pandemi Covid-19 yang sedang berlangsung saat ini, financial technology berbasis syariah khususnya dalam penggunaan instrumen zakat, infak, sedekah dan wakaf dapat dimanfaatkan sehingga diharapkan mampu berperan secara optimal dalam meningkatan aktivitas sosial. Artinya, jangkauan dari pemanfaatan aktivitas yang berbasis syariah dari financial technology menjadi relatif luas, bukan hanya dalam ruang lingkup bisnis untung dan rugi namun bisa juga digunakan kegiatan sosial. Menurut Beik (2020) dalam Puspaningtyas (2020), dimana financial technology syariah berperan sebagai menghubung atau intermediasi antara kelompok yang mempunya kemampuan finansial 
dan bisa bertahan dengan kelompok yang kekurangan dana dan memiliki keterbatasan akibat pandemi Covid-19 ini dengan cara yang akutabel dan dapat diverifikasi.

Kehadiran blockchain ini merupakan hasil inovasi pada era IR 4.0 yang dapat dipergunakan dalam pengelolaan dana wakaf yang mendapatkan respon positif dari masyarakat. Bentuk implementasinya, sebuah perusahaan financial technology asal Singapura (Finterra), telah mengembangkan platform crowdfunding dengan sistem blockchain dalam pengelolaan dana wakaf yang diharapkan mampu menciptakan cara yang lebih efisien dalam pengumpulan dana dan mengelola transfer wakaf yang menerima sumbangan dari umat Islam untuk proyek-proyek sosial tertentu secara spesifik. Sedangkan pengelolaan dana wakaf di Indonesia, Badan Wakaf Indonesia sudah bekerjasama dengan United Nations Development Programmme untuk meningkatkan tata kelola manajemen wakaf dengan menggunakan sistem blockchain (Puspaningtyas, 2020). Hal inilah yang menunjukkan komitmen untuk mengembangkan ekonomi syariah melalui inovasi instrument keuangannya. Pengelolaan dana wakaf menggunakan sistem blockchain ini sejalan dengan Sustainable development program (SDGs), dimana program pembiyaan yang besar tidak dapat hanya mengandalkan pendaan yang tradisional, sehingga inovasi dalam instrument keuangan khususnya syariah terus dikembangkan.

Menurut Sukmana (2019) dimana pengelolaan wakaf produktif dengan menggunakan sistem blockchain memungkinkan terjadinya peningkatan efisiensi dan efektivitas pengelolaan dari dua sisi, yaitu: (1) jika nazhir dan waqif terhubung dalam satu sistem blockchain maka transaksi donasi wakaf dapat dilakukan dengan tingkat transparansi yang cukup tinggi; (2) apabila wakaf berbasis blockchain dapat menjangkau nazhir global maka sangat memungkinkan waqif dari suatu negara untuk berwakaf di negara lain, utamanya negara yang sedang membutuhkan pendanaan untuk pembangunan. Hal yang sama juga diungkapkan oleh Rozi (2020) dalam Puspaningtyas (2020), dimana pengelolaan dana wakaf dengan sistem blockchain, dilakukan untuk mendorong agar pengelolaan dana wakaf lebih akuntabel dan terpecaya. Karena sifat dari wakaf cukup fleksibel maka penerapan blockchain dapat dilakukan dengan pertimbangan tidak melanggar prinsip, sehingga seluruh transaksi dari dana wakaf dapat tercatat secara digital dan memnungkinkan seluruh pihak yang terlibat dapat mengawasi jalannya pengelolaan dana wakaf.

Dalam tatanan regulasi sebagai payung hukumnya, Otoritas Jasa Keuangan dan Bank Indonesia yang bertindak sebagai regulator sudah mengeluarkan regulasi terkait pegelolaan financial technology melalui Peraturan OJK Nomor 77/POJK.01/2016 tentang Layanan Pinjam Meminjam Uang Berbasis Teknologi Informasi dan peraturan PBI 18/40/PBI/2016 tentang penyelanggaraan pemrosesan transaksi pembayaran. Namun yang menjadi catatan adalah belum secara spesifik financial technology berbasis syariah, walaupun beberapa startup atau instansi sudah mulai bermunculan. Keseluruhan peraturan maupun prinsip atas pengelolaan wakaf di Indonesia tersebut sudah cukup komprehensif dan berusaha tidak bertentangan dengan peraturan Basel Core Principles (BCPs) yang dikeluarkan oleh Bank for International Settlement (BIS) tertutama yang berkaitan dengan pengelolaan wakaf secara keseluruhan yang berbasis pada financial technology. Sehingga diharapkan dengan pengelolaan wakaf yang lebih modern dan komprehensif ini mampu mempermudah untuk bertransaksi, mempermudah dalam mengakses produk keuangan dan meningkatkan literasi keuangan masyarakat sehingga pada akhirnya memiliki multiplier effect pada kondisi perekonomian. Oleh karena itu, pengoptimalan kinerja pengelolaan dana wakaf dengan sistem blockchain, dapat menjadi solusi yang ideal bagi pengadaan alat pelindung diri yang saat ini sedang dibutuhkan, mengingat jumlah masyarakat yang menjadi suspek dari Covid-19 di Indonesia semakin bertambah banyak sejak Desember 2019. 
Berdasarkan latar belakang masalah tersebut, terdapat upaya untuk berkontribusi dalam penanganan pandemi Covid-19 ini melalui pengelolaan dana crowdfunding dengan basis instrumen wakaf yang dikelola menggunakan platform blockchain. Sehingga penelitian ini berusaha untuk pembentukan dan pengembangan skema waqf blockchain yang ideal dalam pengadaan kebutuhan alat pelindung diri yang dibutuhkan sebagai upaya penanganan Covid-19 berbasis instrumen keuangan Islam. Oleh karena itu dirumuskan pertanyaan penelitian sebagai berikut: Bagaimana bentuk implementasi waqf blockchain sebagai upaya dalam penanganan Covid-19?

\section{Teori dan Metode}

\subsection{Gambaran Umum Pengelolaan Dana Wakaf}

Pelaksanaan pengelolaan dana wakaf sebagai salah satu instrumen filantropi yang memiliki sejumlah komponen sebagai satu kesatuan yang tidak dapat terpisahkan, antara lain:

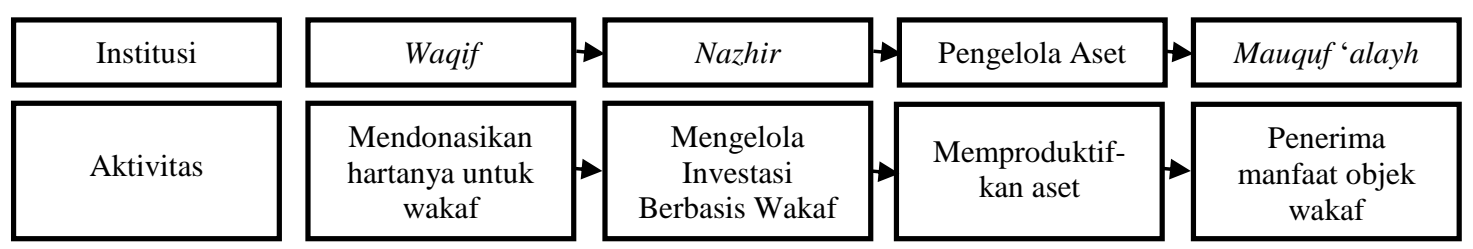

Sumber: (Departemen Ekonomi dan Keuangan Syariah Bank Indonesia dan Departemen Ekonomi Syariah Fakultas Ekonomi dan Bisnis Universitas Airlangga, 2010)

\section{Gambar 1. Skema Wakaf}

Tentunya ketika skema tersebut dilaksanakan oleh masing-masing institusi maka akan menghasilkan multiplier effect yang besar bagi sosio-ekonomi. Namun yang perlu menjadi catatan dalam pelaksanaan pengelolaan dana wakaf ini diperlukan sebuah regulator yang bertanggung jawab dalam membuat aturan perundang-undangan serta melakukan supervisi atas pengelolaan dana wakaf yang dilakukan oleh nazhir.

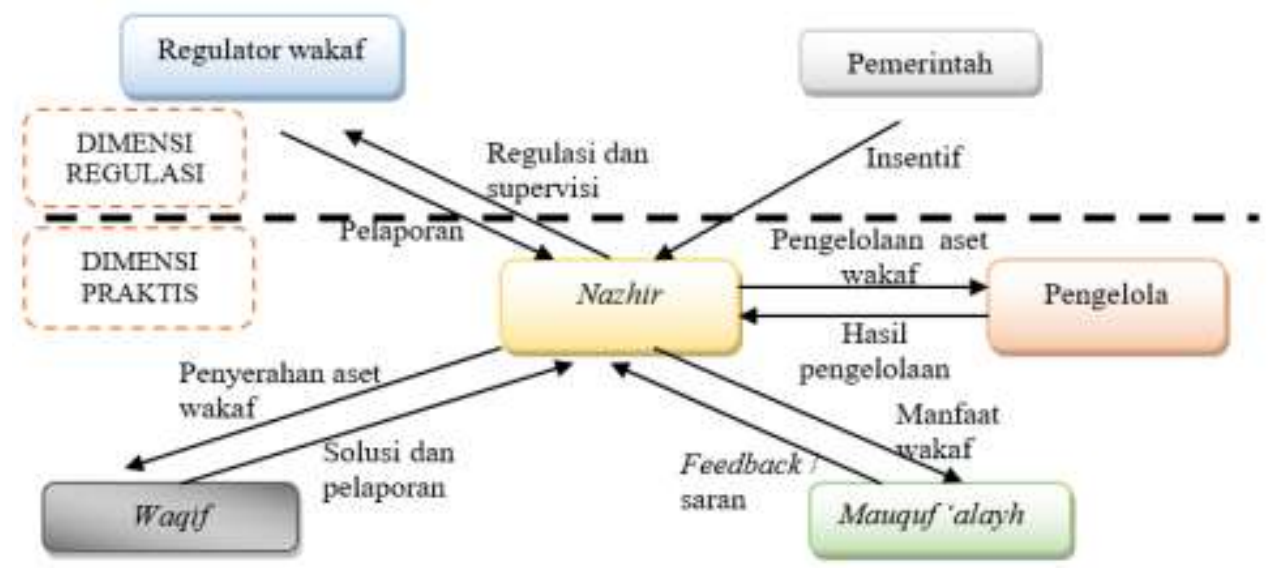

Sumber: (Departemen Ekonomi dan Keuangan Syariah Bank Indonesia dan Departemen Ekonomi Syariah Fakultas Ekonomi dan Bisnis Universitas Airlangga, 2010)

\section{Gambar 2. Sistem Wakaf}

Penggunaan sistem blockchain terutama dalam pengelolaan dana wakaf tergolong baru bukan hanya di Indonesia bahkan di negara maju sekalipun. Padahal sistem ini mengadopsi teknologi yang digunakan pada sistem mata uang bitcoin yang sudah ada sejak satu dekade terakhir. Melihat historisnya pengelolan dana wakaf yang sudah ada sejak 
kurang lebih 1000 tahun yang lalu dimana puncaknya berada pada zaman Kerajaan Otoman yang meliputi kegiatan penyumbangan bangunan, tanah dan aset lainnya dengan tujuan keagamaan tanpa bermaksud untuk mereklamasi aset tersebut.

Cara kerja dari sistem blockchain ini terdiri atas buku besar semua transaksi yang terdesentralisasi ke dalam jaringan P2P, sehingga dengan teknologi ini peserta dapat mentransfer nilai yang diinginkan. Selain itu teknologi blockchain ini merupakan catatan digital yang mencatat setiap transaksi yang tersebar di banyak komputer (node). Berkat sistem blockchain ini transaksi bisa diproses tanpa melibatkan pihak ketiga atau organisasi khusus. sehingga berpotensi dapat meningkatkan efisiensi dalam pengelolaannya Dimana praktik dari pengelolaan dana wakaf dijelaskan dalam Gambar berikut:

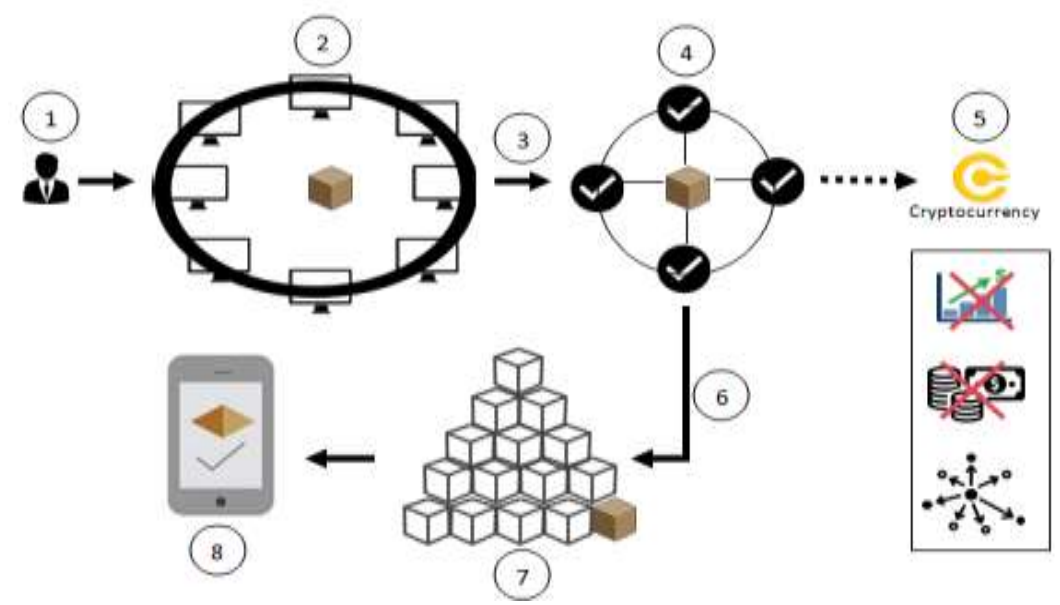

Sumber: Thottathil (2018), dimodifikasi

\section{Gambar 3. Bagaimana Cara Kerja Sistem Blockchain}

Keterangan:

1. Seorang pengguna mengajukan permohonan transaksi

2. Permohonan transaksi yang diminta pengguna tadi kemudian diteruskan ke jaringan $\mathrm{P} 2 \mathrm{P}$ yang terdiri dari beberapa pengguna atau komputer lainnya (dikenal sebagai nodes atau simpul)

3. Memvalidasi atau otentifikasi jaringan nodes, jaringan nodes kemudian divalidasi guna mengetahui keaslian dari transaksi dan status pengguna dengan menggunakan algoritma khusus dalam sistem cryptography

4. validasi dapat berupa transaksi, kontrak, catatan kejadian atau informasi lainnya

5. Cryptocurrency, terdiri atas: (a) Tidak memiliki nilai intrinsik. Dalam hal ini tidak dapat ditebus dengan komoditas lainnya termasuk emas; (b) Tidak memiliki bentuk fisik (hanya berupa jaringan); (c) Penawarannya tidak ditentukan oleh bank sentral dan jaringannya sepenuhnya terdesentralisasi

6. Setelah diverifikasi, transaksi-transaksi yang digabungkan dengan transaksi lainnya guna membuat blok data yang baru untuk buku besar.

7. Blok data yang baru kemudian ditambahkan ke dalam susunan blockchain yang terdiri atas blok-blok yang lain yang sudah, dimana sambungan ini melibatkan parameter yang unik dan saling terhubung sehingga tidak dapat dimodifikasi atau diubah kembali karena sifatnya permanen di kemudian hari

8. Secara permanen dan tidak dapat diubah kembali

9. Transaksi telah berhasil

\subsection{Metode Penelitian}

Jenis penelitian menggunakan pendekatan kualitatif. Dimana penerapannya mempertimbangkan data yang diperoleh dilapangan berupa angka dan fakta terkait dengan 
penyebaran pandemik Covid-19 di Indonesia yang memerlukan analisis yang mendalam untuk pembentukan skema waqf blockchain yang ideal dalam pengadaan kebutuhan alat pelindung diri yang dibutuhkan sebagai upaya penanganan Covid-19 berbasis instrumen keuangan Islam. Hal ini penting mengingat keterbaharuan dari skema dan instrumen yang digunakan berbasis wakaf yang dikelola dengan platform blockchain yang modern, sehingga diharapkan pengelolaannya menjadi lebih optimal. Penggunaan dana wakaf selain untuk kepentingan produktif dapat dipergunakan untuk kegiatan sosial, selain itu masifnya dana wakaf yang belum dioptimalkan menjadi alasannya lainnya kenapa harus menggunakan dana wakaf. Harapannya pengelolaan dana wakaf untuk proyek sosial tertentu secara spesifik khususnya dalam penyediaan alat pelindung diri sebagai upaya dalam penanganan Covid-19 yang sedang berlangsung saat ini dan kedepannya dapat dipergunakan untuk kemaslahatan umat.

Terkait dengan data yang digunakan, merupakan data sekunder yang diperoleh dari berbagai macam sumber seperti literatur, jurnal kajian, laporan dipublikasikan oleh pemerintah atau badan atau instansi tertentu yang mampu mendukung hasil dari penelitian ini, sehingga pembentukan skema terhadap waqf blockchainnya akan menjadi ideal.

Hal yang menjadi titik fokus dari penelitian ini adalah pembentukan dan pengembangan skema dari pengelolaan dana wakaf berbasis platform crowdfunding dengan sistem blockchain untuk kepentingan proyek sosial tetrtentu secara spesifik khususnya dalam penyediaan alat pelindung diri sebagai upaya dalam penanganan Covid19 yang sedang berlangsung pada saat ini. Salah satu manfaat nyata yang dapat diperoleh atas penggunaan blockchain ini pengelolaan wakaf akan menjadi lebih optimal, mulai dari pengimpunan, pengelolaan dan pengembangan dana wakaf secara spesifik serta dapat didistribusikan secara tepat sasaran, sehingga transparansi pengelolaan dana wakaf dapat lebih baik. Karena kunci keberhasilan dari pemberdayaan wakaf terletak pada mekanisme pendistribusian dan pengelolaan yang tepat guna sehingga akan memberikan kebermanfaatn sosial atau membawa kepada maslahat umat (Rashid, 2018).

\section{Hasil dan Pembahasan}

\subsection{Perkembangan Kasus Covid-19 di Indonesia}

Sejak 31 Desember 2019, menjadi awal mula penyakit Wuhan Pneumonia yang disebabkan oleh Coronavirus Disease 2019 muncul. Per tanggal 11 Maret 2020, WHO mulai menetapkan kondisi "kedaruratan kesehatan masyarakat yang meresahkan dunia" atau pandemi karena penyakit ini menyebabkan menular dengan cepat kepada manusia serta dapat mengakibatkan angka kematian yang cukup tinggi. Sedangkan untuk kasus Covid-19 di Indonesia, per tanggal 14 Maret 2020 pemerintah menetapkan sebagai bencana nasional. Seiring waktu jumlah kasus mengalami peningkatan (lihat Gambar 4), sehingga diperlukan upaya yang kompregensif dalam memutus rantai penularan. 

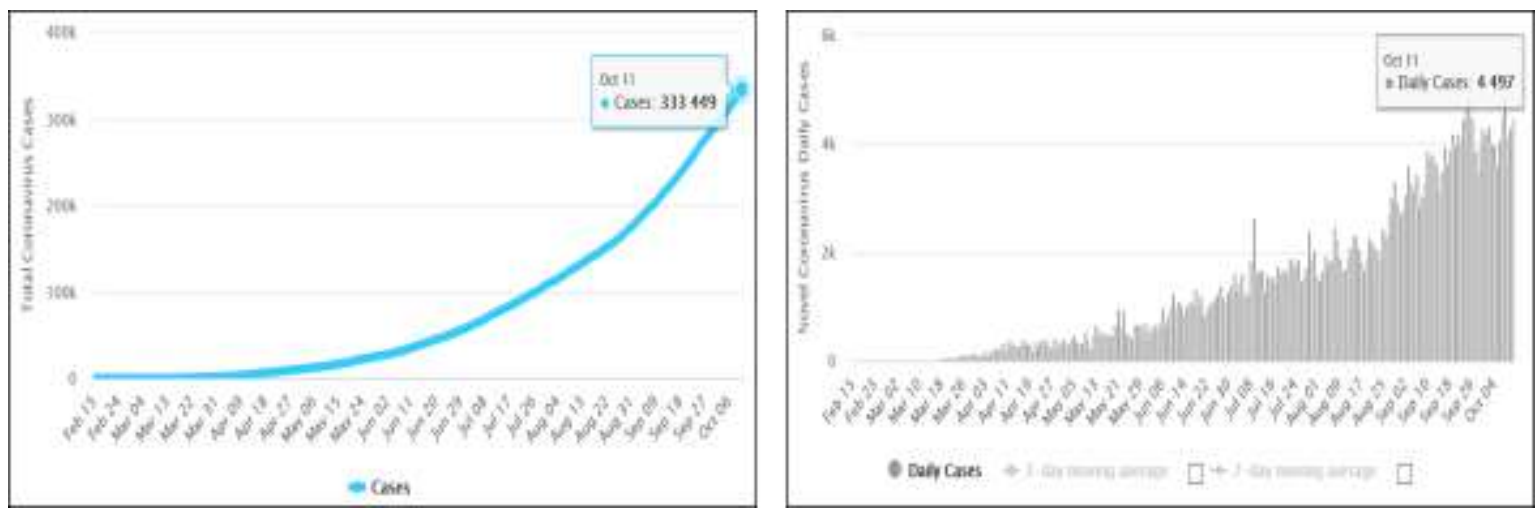

Sumber: Worldometer (2020); Gugus Tugas Percepatan Penanganan Covid-19 (2020)

Gambar 4. Jumlah Kasus dan Penambahan Kasus Harian Pandemi Covid-19 di Indonesia (Per 11 Oktober 2020)

Menurut data dari Gugus Tugas Percepatan Penanganan Covid-19 (2020), angka kasus dan tambahan jumlah per hari Covid-19 di Indonesia sampai per 11 Oktober 2020 berfluktuatif dan memiliki tren yang positif. Dari 34 provinsi dan 500 kota atau kabupaten yang ada di Indonesia jumlah pasien yang terkonfirmasi mencapai 333.449 orang, mengalami peningkatan sebesar 4.497 pasien dari hari sebelumnya, sedangkan pasien yang berhasil sembuh mencapai 255.027 pasien yang meningkat sebesar 3.546 pasien dari hari sebelumnya, untuk pasien yang meninggal dunia sebesar 11.844 pasien meningkat sebesar 79 pasien pada hari sebelumnya. Kondisi ini menempatkan Indonesia berada urutan ke 20 di dunia

\subsection{Kebutuhan Alat Pelindung Diri untuk Tenaga Medis dalam Penanganan Pasien Suspect Covid-19}

Menurut Peraturan Menteri Tenaga kerja dan Transmigrasi (Per.08/MEN/VII/2010) mendefinisikan alat pelindung diri sebagai alat yang dibutuhkan dan digunakan oleh seorang tenaga kerja dengan fungsi untuk melindungi sebagian atau seluruh anggota tubuhnya terhadap potensi bahaya dan risiko kecelakaan kerja. Alat pelindung diri merupakan bagian dari perlengkapan keselamatan kerja yang wajib digunakan karena dapat meminimalisir dari potensi cedera dan penyakit serius terkait pekerjaan. Penggunaan alat pelindung diri berbeda, tergantung dari jenis profesi yang dijalankan, misalnya antara alat pelindung diri yang digunakan oleh kontraktor tidak akan sama dengan yang digunakan oleh laboran ataupun tenaga medis.

Menurut Direktorat Jenderal Kefarmasian dan Alat Kesehatan, Kementerian Kesehatan Republik Indonesia (2020) juga mengatur secara terperinci untuk alat pelindung diri yang digunakan dalam bidang kesehatan, dimana antara penggunannya pun baik yang digunakan oleh dokter, perawat atau orang yang mentransfer pasien juga bervariasi karena berkaitan dengan tujuan keperluan penggunaan alat pelindung diri dan kondisi yang ada di lapangan seperti ruangan atau lokasi penggunaan, penyesuaian atas tingkatan keparahan dari dialami oleh pasien, penyakit atau virus yang dihadapi. Penggunaan alat pelindung diri ini harus sesuai dengan protokol kesehatan oleh World Health Organization (WHO), Pusat Centers for Disease Control and Prevention (CDC), Kementerian Kesehatan, dan Ikatan Dokter Indonesia yang berlaku, dimana dokter, perawat, dan tenaga medis wajib menggunakan alat pelindung diri selama menangangi pasien suspect dari Covid-19 (lihat Tabel 1). 
Tabel 1. Rekomendasi APD Berdasarkan Tingkat Perlindungan

\begin{tabular}{|c|c|c|c|}
\hline $\begin{array}{l}\text { Tingkat } \\
\text { perlindung } \\
\text { an }\end{array}$ & Kelompok & Lokasi atau Cakupan & Alat Pelindung Diri \\
\hline \multirow{7}{*}{$\begin{array}{l}\text { Tingkat } \\
\text { Perlindung } \\
\text { an } 1\end{array}$} & Masyarakat umum & Fasilitas umum & Masker kain; masker bedah 3 ply \\
\hline & $\begin{array}{l}\text { Kelompok lainnya (cleaning } \\
\text { service, satpam, pertugas } \\
\text { adminisitrasi, pendamping } \\
\text { orang sakit) }\end{array}$ & Fasilitas umum & $\begin{array}{l}\text { Masker bedah } 3 \text { ply; sarung } \\
\text { tangan kerja (bukan sarung tangan } \\
\text { karet yang sekali penggunaan) }\end{array}$ \\
\hline & $\begin{array}{l}\text { Petugas penanganan cepat } \\
\text { atau investigator atau } \\
\text { relawan yang melakukan } \\
\text { wawancara } \\
\text { terhadap pasien ODP dan } \\
\text { PDP }\end{array}$ & $\begin{array}{l}\text { Fasilitas umum (kegiatan harus } \\
\text { dilakukan di luar rumah) }\end{array}$ & Masker bedah 3 ply \\
\hline & \multirow{2}{*}{ Dokter dan perawat } & $\begin{array}{lcr}\text { Tempat praktik umum } & \text { dan } \\
\text { kegiatan } & \text { yang } & \text { tidak } \\
\text { menimbulkan aerosol } & \end{array}$ & $\begin{array}{lrrr}\begin{array}{l}\text { Masker } \\
\text { tangan }\end{array} \text { karet } & \text { yly; } & \text { sang } & \text { sekali } \\
\text { penggunaan } & & \end{array}$ \\
\hline & & $\begin{array}{l}\text { Triase pra-pemeriksaan bagian } \\
\text { rawat jalan umum }\end{array}$ & $\begin{array}{lrrr}\text { Masker bedah } & 3 \text { ply; } & \text { marung } \\
\text { tangan karet } & \text { yang } & \text { sekali } \\
\text { penggunaan } & & \end{array}$ \\
\hline & \multirow[t]{2}{*}{ Supir ambulance } & $\begin{array}{l}\text { Ambulans, ketika membantu } \\
\text { menaikkan dan menurunka } \\
\text { Covid-19 }\end{array}$ & $\begin{array}{l}\text { Masker bedah } 3 \text { ply; sarung } \\
\text { tangan karet yang sekali } \\
\text { penggunaan; gown (menghindari } \\
\text { risiko percikan cairan tubuh) }\end{array}$ \\
\hline & & $\begin{array}{l}\text { Ambulans, tidak kontak } \\
\text { langsung dengan pasien }\end{array}$ & Masker bedah 3 ply \\
\hline \multirow{3}{*}{$\begin{array}{l}\text { Tingkat } \\
\text { Perlindung } \\
\text { an } 2\end{array}$} & \multirow{2}{*}{ dokter dan perawat } & $\begin{array}{l}\text { Ruangan poliklinik } \\
\text { praktek pemeriksaan } \\
\text { yang memiliki gejala } \\
\text { pernafasan }\end{array}$ & $\begin{array}{l}\text { Masker bedah } 3 \text { ply; gown } \\
\text { (menghindari risiko percikan } \\
\text { cairan tubuh); sarung tangan karet } \\
\text { yang sekali penggunaan; } \\
\text { pelindung mata (face shield - kaca } \\
\text { mata medis) }\end{array}$ \\
\hline & & Ruang tempat perawatan pasien & $\begin{array}{l}\text { Masker bedah } 3 \text { ply; gown } \\
\text { (menghindari risiko percikan } \\
\text { cairan tubuh); sarung tangan karet } \\
\text { yang sekali penggunaan; } \\
\text { pelindung mata (face shield - kaca } \\
\text { mata medis) }\end{array}$ \\
\hline & dokter, perawat atau petugas & Pengambilan sampel dari non & Masker bedah 3 ply; gown \\
\hline
\end{tabular}




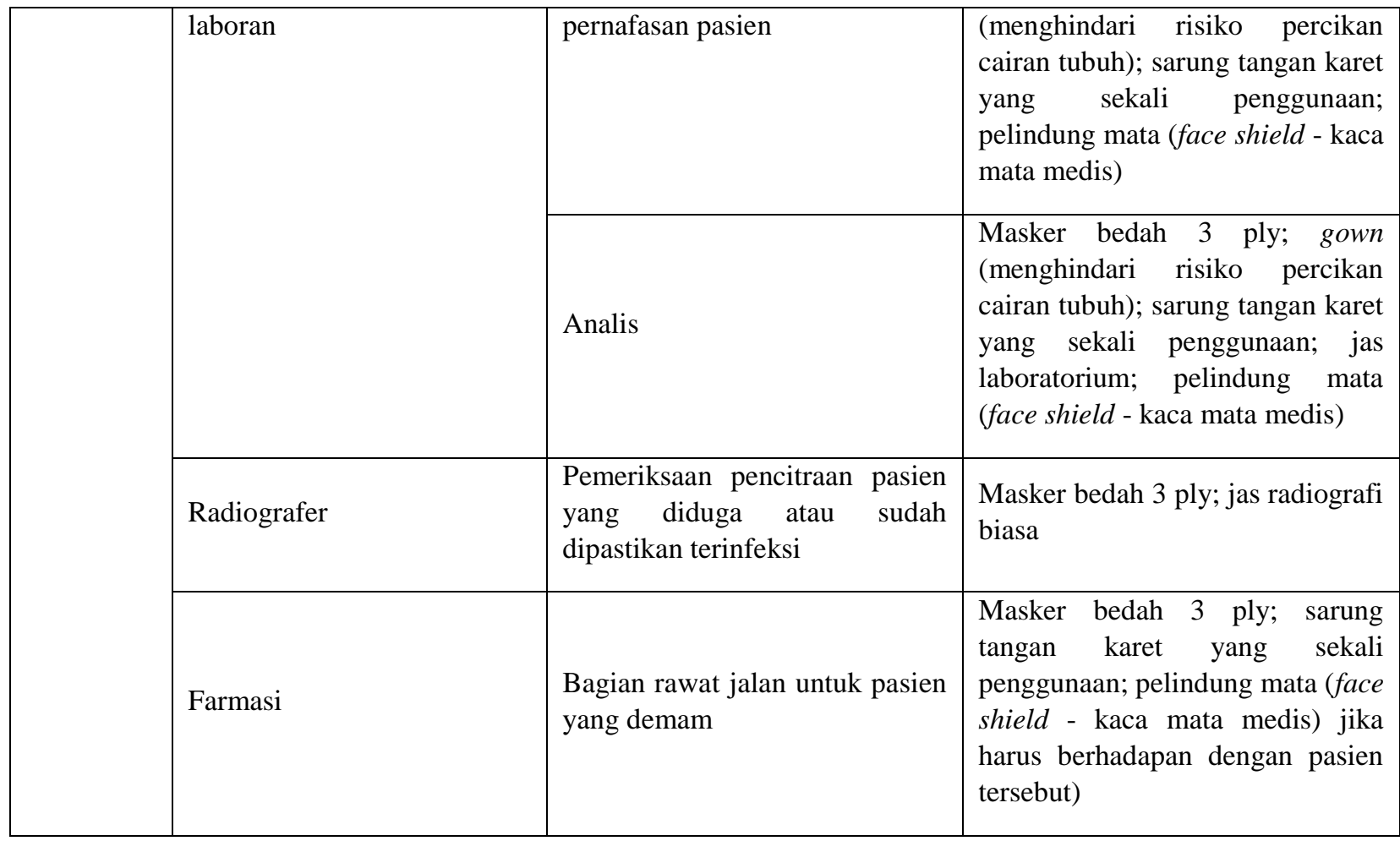

Sumber: Direktorat Jenderal Kefarmasian dan Alat Kesehatan, Kementerian Kesehatan Republik Indonesia (2020).

Dalam konteks penanganan dan merawat pasien suspect dari Covid-19 ini alat pelindung diri sangat dibutuhkan. Kriteria yang ideal dalam penggunaan alat pelindung diri ini, antara lain Wibowo (2020) dalam Nugraheny (2020): (1) alat pelindung diri harus mampu memberikan rasa aman dari bahaya yang secara spesifik baik secara kontak langsung ataupun tidak; (2) bahan yang digunakan seringan mungkin sehingga memberikan kenyamanan tetapi tidak mengabaikan faktor keselamatan; (3) terkait daya tahan, alat pelindung diri menggunakan bahan yang cenderung tidak mudah rusak. Sehingga anggaran dalam pengadaan alat pelindung diri relatif besar. Hal ini dibenarkan Aini (2020) dalam Yohanes (2020) salah seorang dokter di rumah sakit rujukan regional RSUD dr Iskak Tulungagung menyebutkan bahwa dalam satu hari biaya khusus untuk pengadaan alat pelindung diri tenaga medis mencapai Rp 10 juta, ini diluar dari biaya ruang perawatan, biaya dokter dan obat-obatan. Besarnya anggaran ini dengan rincian alat pelindung diri yang satu kali penggunaan, seperti baju terusan (hazmat model coverall), penutup kepala, sarung tangan bedah karet yang steril, dan masker N-95 (yang hanya dapat dipakai dengan rentang empat hingga enam saja) serta alat pelindung diri yang dapat dipergunakan 
berulang kali, seperti sepatu boots berbahan karet dan pelindung mata (kaca mata medis) yang dibersihkan dengan prosedur kesehatan menggunakan cairan chlorin.

Jumlah kebutuhan alat pelindung diri ini tentunya berbeda pada setiap rumah sakit rujukan atau non rujukan dari penanganan Covid-19. Pada umumnya setiap rumah sakit yang menjadi rujukan dalam penanganan Covid-19 ini membagi menjadi dua shift kerja (12 jam kerja) atau tiga shift kerja (delapan jam kerja). Masing-masing shift kerja ini terdiri dari lima atau enam tenaga medis. Artinya kebutuhan dari alat pelindung diri ini dikalikan dengan beraapa pasien yang dirawat. Hal ini juga dibenarkan oleh Sumardi (2020) dalam fajarsatu.com (2020), seorang dokter dan Direktur dari RSD Arjawinangun yang menyebutkan faktanya satu orang yang positif atau terduga positif Covid-19 atau bahkan yang meninggal dunia, pihak rumah sakit perlu untuk menyiapkan minimal 20 alat pelindung diri, artinya anggaran yang dibutuhkan mencapai Rp 15 juta.

Prediksi kedepannya kebutuhan alat pelindung diri diestimasikan mencapai 12 juta paket selama empat bulan kedepan, potensi permintaan juga dapat meningkat hingga 100 - 500 persen (Kementerian Perindustrian, 2020 dalam Hidayat, 2020). Sebagai contoh, Provinsi DKI Jakarta sebagai provinsi dengan tingkat pasien Covid19 tertinggi di Indonesia mengalami peningkatan permintaan dari alat pelindung diri mencapai 10.000 paket perharinya atau meningkat sebesar 100 persen. Menurut Handoyo (2020) salah seorang anggota Komisi IX DPR RI mendesak pemerintah melalui mekanisme kerjasama dengan beberapa pabrik dalam pengadaan kebutuhan alat pelindung diri yang masih kurang dalam penanganan Covid-19 ini, dan seharusnya biaya produksi dan pengadaan bukan masalah utama. Hal ini mengingat Pemerintah Pusat melalui Kementerian Keuangan menyiapkan tambahan anggaran sebesar Rp 405,1 triliun pada APBN 2020, dimana salah satu pos pembelanjaannya diperuntukkan untuk pengadaan alat pelindung diri bagi tenaga kesehatan sebesar Rp 65,8 triliun atau 16 persen.

\subsection{Pengadaan Alat Pelindung Diri dengan Skema Waqf Blockchain}

Dalam hal ini walaupun pengadaan alat pelindung diri berada sepenuhnya menjadi tanggung pemerintah. Namun masifnya angka suspect Covid-19 ini, baik ODP, PDP ataupun yang positif membuat masyarakat ikut berkontribusi dalam upaya memutus rantai penyebaran virus. Berbagai platform digital dan lembaga kemanusiaan pun juga berpatisipasi dalam penanganan pandemic ini, dimana salah satu yang berdampak signifikan yaitu membuka penggalangan donasi dengan berbagai tujuan, termasuk dengan pengadaan APD yang sedang dibutuhkan oleh relawan dan tenaga medis. Tingginya jumlah dana yang berhasil dikumpulkan ini menjadi bukti bahwa rasa solidaritas dan kehidupan bersosial masyarakat Indonesia 
relatif tinggi. Hal ini dibenarkan oleh Charities Aid Foundation, (2016), yang memasukkan Indonesia ke dalam salah satu dari 10 negara di dunia dengan indeks kedermawanan yang tertinggi mencapai 56 persen.

Dalam konteks penanganan pandemi ini, menurut Palmer (2020) dalam Ridhoi (2020) tingkat kedermawanan yang tinggi ini akan menjadi sia-sia atau tidak efektif ketika tidak tepat sasaran. Mengingat pandemi ini berjalan dengan rentang yang relatif panjang, sehingga membutuhkan strategi yang tepat guna agar donasi yang disalurkan oleh masyarakat dapat bermanfaat secara maksimal. Penyebaran Virus Covid-19 yang cepat ini menjadi permasalahan yang serius dan kompleks, bukan hanya membuat individu menjadi jatuh sakit baik dengan gejala ataupun tidak yang membutuhkan perawatan medis yang lebih intens bahkan dapat menyebabkan meninggal dunia. Jauh dari pada itu, pandemi ini berpotensi menyebabkan gangguna dalam perekonomian suatu negara. Misalnya kebijakan lockdown dalam suatu wilayah atau teritorial tertentu sebagai bentuk perluasan dari social distancing yang lebih dulu dikeluarkan oleh Pemerintah, sehingga dalam hal ini membatasi mobilitas masyarakat sehingga akan berpengaruh terhadap kondisi sosio-ekonomi walaupun dengan maksud pencegahan pandemi ini (Yunus dan Reski, 2020; Neneng 2020).

Dalam menghadapi pandemi ini terbentuklah pola pikir yang baru, untuk lebih berempati dan peka terhadap perubahan-perubahan sosial di masyarakat. Sebagai contoh yang sederhana, untuk memikirkan masyarakat yang ada di sekitar lingkungan kerja dalam memberikan donasi, bisa tetangga, kawan, kerabat, tenaga medis atau rumah sakit terdekat. Tentunya dengan bantuan yang kita berikan akan sangat bermanfaat bagi mereka, karena secara logikanya seseorang sudah pasti mengetahui dengan pasti akan kebutuhan orang yang berada disekitarnya atau minimal mereka tidak akan kesulitan dalam menanyakan kebutuhannya.

Salah satu cara yang terbaik dalam melakukan hal ini, dengan menggunakan instrumen keuangan Islam berupa pengelolaan dana wakaf, yang dipadukan dengan platform berbasis blockchain. Dari sini yang menjadi pertanyaan besarnya adalah kenapa harus menggunakan dana wakaf, dan penggunaan platform blockchain? Menurut Anggraito (2020), bahwa dengan penggunaan sistem blockchain ini dalam pengelolaan dana wakaf, bukan hanya dipergunakan untuk kepentingan yang produkti saja, namun bisa menyentuh kepada sektor sosial. Hanya saja masih diperlukan penelitian dan pengembangan terutama terkait dengan pemenuhan sumber daya manudia yang berkompeten (dalam hal ini adalah nazhir) dan regulasi dan governance yang mendukung agar menemukan sebuah konsep yang ideal, khususnya pada kebutuhan sosialnya. 


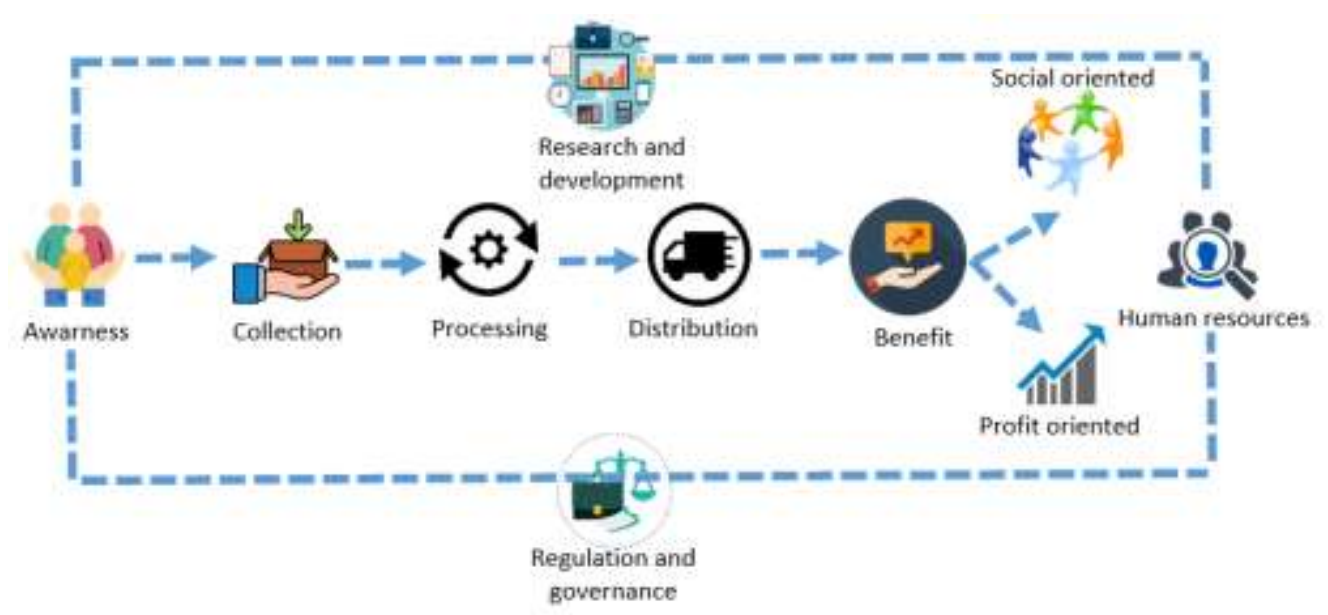

Sumber: Anggraito (2020); Sukmana, (2020), dimodifikasi

\section{Gambar 5. Value Chain dari Penerapan Waqf Blockchain}

Dari Gambar 5, menunjukkan bahwa starting point dari pengeloaan dana wakaf dimulai dari pengumpulan yang bersumber pada pendonor internasional, dana CSR perusahaan, atau pendonor dalam negeri, kemudian dana wakaf tersebut diproduktifkan sehingga hasilnya akan didistribusikan kepada yang membutuhkan, sehingga keuntungannya akan dapat dirasakan oleh kedua sektor, antara berorientasi sosial (kemanusian, pendidikan, kesehatan, dakwah) dan berorientasi pada keuntungan (difokuskan pada industri halal).

Proses pengaplikasian platform blockchain dalam pengelolaan dana wakaf ini merupakan bentuk keterbaharuan dan inovasi sehingga menghasilkan manajemen yang efisien dan optimal, sehingga mendapatkan sambutan positif dari masyarakat. Salah satu perusahaan financial technology asal Singapura, Finterra yang juga sudak mencoba untuk mengaplikasikan dan pengembangan sistem ini, membuktikan bahwa pengelolaan wakaf akan menciptakan efisiensi dan efektivitas pengelolaan dana wakaf, mulai dari pengumpulan, pengelolaan, pengembangan dan pendistribusian terkait proyek-proyek yang secara spesifik.

Cara kerja yang efektif dari platform blockchain ini menyerupai sistem pada buku besar yang mencatat keseluruhan transaksi yang membentuk sebuah rantai satu kesatuan yang utuh. Setiap transaksi akan membentuk sebuah blok tertentu, dimana dalam keseluruhan sistem terdiri dari beberapa blok yang menggambarkan keseluruhan transaksi yang sudah dilaksanakan. Penghubung antarblok mengunakan algoritma kriptografi. Pencegahan terjadi double entry dalam sistem, platform ini menggunakan time-stamp yang akan mencatat setiap transaksi berlangsung. Sebagai fungsi pengamanan dalam pencatatannya, sistem ini menggunakan crypography signatures and public key infrastructure. Dimana masing-masing user kemudian menyimpan catatan transaksi yang sudah dilaksanakan, karena transaksi tersebut 
kemudian direplikasikan dan distribusikan kepada user melalui sistem ini. Dengan hadirnya platform blockchain ini setiap transaksi dapat diproses tanpa melibatkan pihak ketiga sehingga meningkatkan efisiensi dalam pengelolaannya (lihat Gambar $6)$.

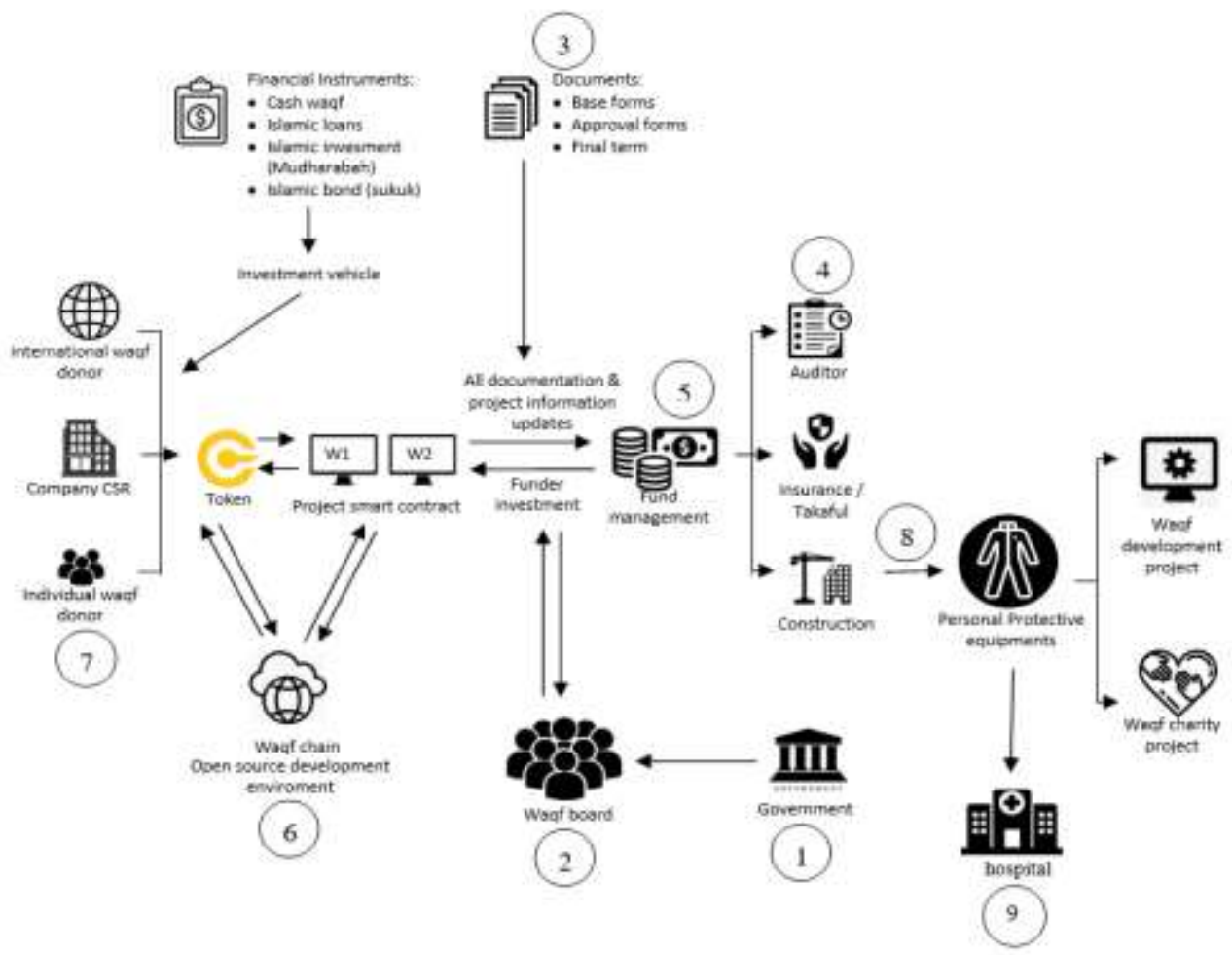

Sumber: Rashid (2018); Thottathil (2018); Sukmana, (2020),dimodifikasi

\section{Gambar 6. Skema Pengelolaan Dana Wakaf Berbasis Teknologi Blockchain}

Mekanisme teknologi blockchain dapat mendukung pengadaan alat pelindung diri dengan memanfaatkan pengelolaan dana wakaf dijelaskan dibawah ini:

1. Pemerintah bekerjasama dengan waqf board dalam pengadaan alat pelindung diri untuk penanganan Covid-19

2. Waqf board melakukan identifikasi dan menyediakan aset untuk dikembangkan sebagai objek dari pengelolaan wakaf

3. Semua dokumentasi dan informasi yang mencakup studi kelayakan; rencana proyek pembangunan; penetapan biaya proyek; dan instrumen pembiayaan yang direkomendasikan terus diperbaharui sesuai dengan kebutuhan pengadaan alat pelindung diri

4. Auditor independen mengkaji dan menyetujui dokumentasi proyek pengembangan dan memberikan rekomendasi bahwa proyek yang akan dijalankan ini kredibel 
5. Fund manager yang memiliki lisensi kemudian dilibatkan untuk meluncurkan Initial Coin Offering (ICO) pengembangan pengelolaan dana wakaf melalui penjualan token kepada para investor secara global.

6. Waqf chain dibangun atas penggunaan open source development enviroment melalui meluncurkan token agar memperoleh dana dalam pelaksanaan project smart contract

7. Investor secara global membeli token, sehingga dana yang berhasil dikumpulkan berada dalam pengelolaan pada fund manager yang ditunjuk. Pada saat investor membeli token mereka diberikan pilihan satu instrumen pembiayaan mana dari empat instrumen yang ada yang akan mereka gunakan, diantaranya: (1) wakaf tunai; (2) keuangan Islam; (3) investasi Islam; (4) obligasi Islam

8. Setelah modal tercapai, fund manager menunjuk perusahaan konstruksi untuk mulai membangun dan mengembangan struktur pengelolaan aset yang dijadikan sebagai objek wakaf. Dalam hal ini dana wakaf yang sudah terkumpul akan segera diadakannya alat pelindung diri yang sedang dibutuhkan, sehingga tercapainya dua tujuan, yaitu: (1) waqf development project; (2) waqf charity project.

9. Setelah selesai diproduksi alat pelindung diri segera dibagikan kepada rumah sakit baik rujukan atau non rujukan sesuai dengan keiniginan dari pendonor.

Proses pengangplikasian dana wakaf untuk pengadaan alat pelindung diri tanpa menggunakan platform blockchain, ditunjukkan oleh ilustrasi berikut:

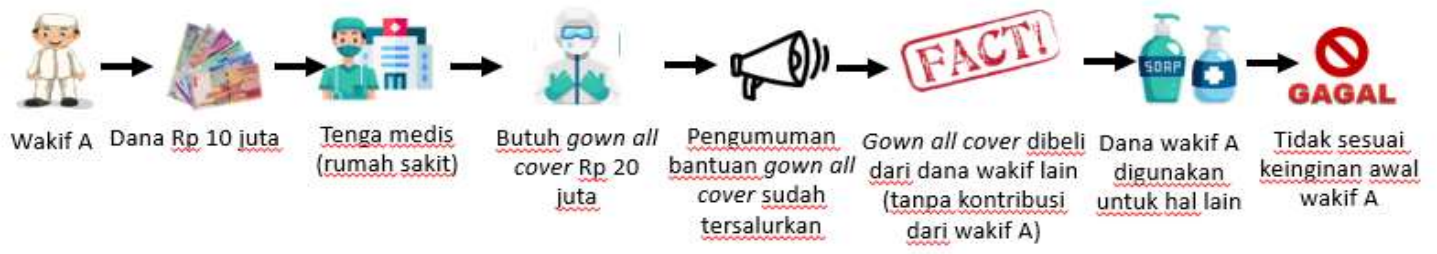

Sumber: Sukmana, (2019), dimodifikasi

\section{Gambar 6. Skema Pengelolaan Dana Wakaf Tanpa Sistem Blockchain}

Ilustrasi sederhana diatas menunjukkan pengelolaan dana wakaf yang diperuntukkan untuk pengadaan alat pelindung diri tanpa menggunakan platform blockchain. Sehingga dalam hal ini berpotensi atas risiko reputasi nazhir, artinya muncul rasa tidak percaya dari pengelolaan wakaf oleh wakif, karena pengelolaan dana wakaf tidak sesuai dengan harapan dan niat dari wakif. Tentunya ini akan menghambat pengelolaan wakaf secara optimal, karena nazhir merupakan pihak yang cukup strategis dalam pengelolaan dana wakaf, mulai dari pengumpulan, pengelolaan, dan pendistribusian dana wakaf (Tiswarni, 2014; Ilyas, 2017; Prasinanda dan Widyastuti 2019). Ketika seorang wakif A memiliki sejumlah dana sebesar Rp 10 juta dan akan mewakafkannya dalam bentuk alat pelindung diri kepada tenaga medis di rumah sakit a seharga Rp 20 juta. Lalu nazhir akan menyampaikan 
kepada wakif yang menyalurkan dananya dalam bentuk wakaf, bahwa dana wakaf dalam bentuk alat pelindung diri kepada tenaga medis di rumah sakit a sudah disalurkan dengan baik. Namun faktanya alat pelindung diri tersebut dibeli berasal dari dana wakif lainnya, tanpa adanya kontribusi dari wakif A. dana dari wakif dipergunakan untuk keperluan laiinya yang tidak sesuai dengan keinginan dan harapan dari wakif A. Dalam hal ini, ada dua kemungkinan ketika pengelolaan dana wakaf tidak optimal: (1) kapasitas atau kemampuan nazhir yang tidak berkompeten atau tidak fokus dalam pengelolaan dana wakaf; (2) wakif juga tidak peka karena kurang peduli ataupun bahkan belum memahami pada status harta benda atau dana yang mereka wakafkan (Usman, 2009; Kasdi, 2014). Setelah itu bandingkanlah ketika pengelolaan dana wakaf dengan menggunakan platform blockchain, seperti ilustrasi berikut:

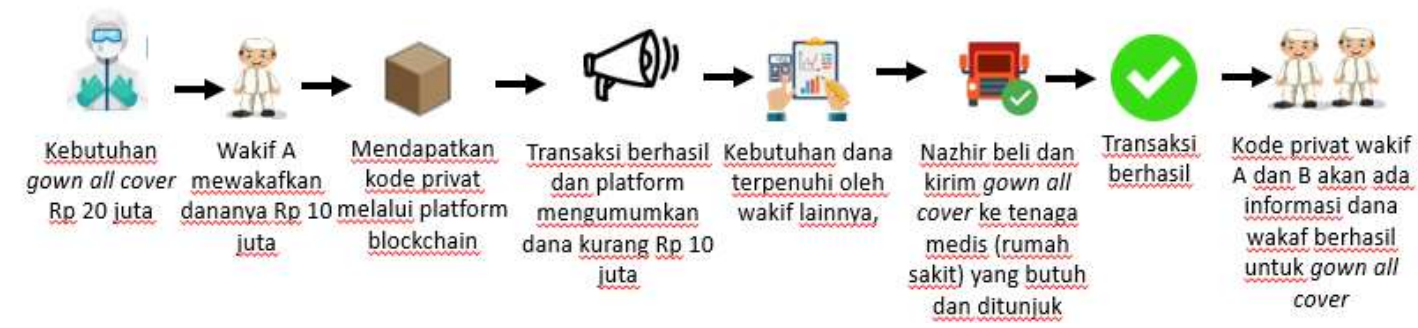

Sumber: Sukmana, (2019), dimodifikasi

\section{Gambar 7. Skema Pengelolaan Dana Wakaf dengan Sistem Blockchain}

Ketika platrom blockchain ini diaplikasikan kepada pengelolaan dana wakaf untuk pengadaan alat pelindung diri kepada tenaga medis di rumah sakit tertentu. Hal ini dapat menjadi keterbaharuan instrument sehingga dapat meningkatkan tranparansi pengelolaan dana wakaf dan meningkatkan kembali rasa kepercayaan kepada nazhir. Berdasarkan ilustrasi diatas menunjukkan bahwa ketika nazhir mengunggah kembali atas kebutuhan alat pelindung diri berupa gown all cover untuk tenaga medis di rumah sakit a, maka wakif a yang mewakafkan dananya sebesar Rp 10 juta rupiah akan mendapatkan kode privat melalui akun platform blockchainnya, ketika transaksi berhasil maka platform tersebut akan mengumumkan bahwa dana yang dibutuhkan kurang Rp 10 juta, dan akan dipenuhi oleh nazhir lainnya yang juga menginginkan dananya dipergunakan untuk membeli alat pelindung diri berupa gown all cover untuk tenaga medis di rumah sakit a dengan mekanisme yang sama dengan wakif a. setelah dana tercukupi kemudia nazhir akan membelikan alat pelindung diri tersebut lalu dikirimkan sesuai dengan keinginan dan harapan dari wakif. Setelah transaksi berhasil maka kode privat yang dimiliki oleh wakif A dan wakif lainnya akan ada informasi bahwa dananya wakafnya berhasil dipergunakan sebagaimana mestinya.

Dalam masa pandemi ini instrument keuangan syariah khususnya dana wakaf harus mampu menjadi sebuah kelaziman baru di masyarakat, sehingga pada akhirnya penggunaan dana wakaf secara produktif dapat optimal untuk mendungkung sumber- 
sumber pembiayaan berbasis syariah yang cukup potensial. Karena selama ini pengelolaan dana wakaf cenderung pada kegiatan ibadah yang lazim seperti masjid, mushalla, sekolah, madrasah, pondok pesantren, dan makam dapat berkembang untuk kepentingan umat baik dari sektor ekonomi, pendidikan, kesehatan (Sa'adah dan Wahyudi, 2016). Kebutuhan alat pelindung diri bagi dokter, perawat dan tenaga medis selama pandemic Covid-19 ini cukup tinggi, yang sejalan dengan jumlah masyarakat yang menjadi suspek dari pandemic ini.

Sehingga untuk mengoptimalkan pengelolaan dana wakaf berbasis blockchain ini, sebagai upaya dalam pemenuhan kebutuhan alat pelindung diri, dapat dilakukan dengan (Badan Wakaf Indonesia, 2020): (1) pemanfaatan teknologi informasi dalam pengelolaan dana wakaf, dimana wakaf blockchain merupakan solusi yang ideal sebagai bentuk digitalisasi pengelolaan dana wakaf yang potensial; (2) sinergisitas antara lembaga pengelolaan wakaf dengan pemerintah, terutama menyangkut hal yang krusial, seperti data dari mauquf 'alayh (peneriman manfaat wakaf) sehingga menjadi tepat sasaran; (3) sinergisitas dengan agenda pembangunan nasional sehingga tujuan pembangunan berkelanjutan dapat berjalan sebagaimana mestinya. Ketika seluruh aspek ini dilaksanakan maka pengelolaan dana wakaf tidak hanya untuk membantu sesama, namun juga dapat memperkuat perekonomi nasional dan mensejahterakan umat. Khusus dalam sektor kesehatan, pengelolaan dana wakaf ini dapat dilakukan untuk memperkuat ketahanan kesehanan nasional saat pandemic Covid-19 sedang berlangsung, sehingga pemenuhan kebutuhan dari alat pelindung diri, obat-obatan, vaksin dan penyediaan layanan kesehatan tidak mengorbankan kemandirian ekonomi nasional.

\section{Kesimpulan}

Pandemi Covid-19 yang terjadi sejak Desember 2019, mendorong berbagai pihak untuk turun tangan secara bersama-sama menanggulanginya. Sebagai upaya dalam penanganan Covid-19, alat pelindung diri dibutuhkan dalam jumlah yang masif baik bagi rumah sakit rujukan maupun non rujukan, termasuk tenaga medis yang sedang menangani suspek dari Covid-19. Dari hari ke hari jumlah alat pelindung diri yang diperlukan meningkat, sejalan dengan semakin banyaknya suspek dari pandemik Covid-19 ini, sehingga jumlah kebutuhan alat pelindung diri ini tergantung dari banyaknya pasien yang dirawat. Berbagai cara dilakukan untuk memenuhi kebutuhan dari alat pelindung diri ini, salah satunya dengan mengadakan penggalangan dana. Dalam era 4.0 saat ini, penggalangan dan dapat dilakukan dengan cara yang lebih praktis namun tetap efektif dan efisien berkat bantuan teknologi. Sehingga peran financial technology dalam menunjang aktivitas penggalangan dana relatif besar, ini tergambarkan dari relatif luasnya keterjangkauan yang dapat diperoleh dengan pemanfaatan teknologi tersebut.

Melihat potensi yang relatif besar namun belum optimal dimanfaatkan, salah satunya melalui instrumen keuangan khususnya berbasis syariah yaitu dana wakaf. 
Selain itu, dengan diaplikasikannya pengelolaan dana wakaf kedalam platform crowdfunding berbasis blockchain, menjadi instrumen ini menjadi lebih berdaya guna dan optimal. Hal ini dilakukan karena mulai dari proses penghimpunan, pengelolaan dan pengembangan dana wakaf secara spesifik serta dapat didistribusikan secara tepat sasaran, sehingga transparansi pengelolaan dana wakaf dapat lebih baik. Harapannya pengelolaan dana wakaf untuk proyek sosial tertentu secara spesifik khususnya dalam penyediaan alat pelindung diri sebagai upaya dalam penanganan Covid-19 yang sedang berlangsung saat ini dan kedepannya dapat dipergunakan untuk kemaslahatan umat

\section{Daftar Pustaka}

Anggraito, Sigit. 2020. "Blockchain Waqf Usecase : Telkom Blockchain Wakaf (Kerjasama Telkom \& BWI)", dipresentasikan pada Forum Kajian Wakaf Seri 01 Tahun 2020, Pengelolaan Wakaf Berbasis Blockchain: Peluang dan Tantangan, Selasa, 21 April 2020, 10.00 - 12.00 WIB.

Badan Wakaf Indonesia. 2020. "Wakaf Sebagai Kelaziman untuk Menyejahterakan Masyarakat”. $\quad$ https://www.bwi.go.id/5323/2020/08/12/wakaf-sebagaikelaziman-untuk-menyejahterakan-masyarakat/

Charities Aid Foundation. 2016. CAF World Giving Index 2016: The World's Leading Study of Generosity. London: Charities Aid Foundation. https://www.cafonline.org/docs/default-source/about-us-publications/1950a wgi_2016_report_web_v2_241016.pdf

Direktorat Jenderal Kefarmasian dan Alat Kesehatan, Kementerian Kesehatan Republik Indonesia. 2020. Standar Alat Pelindung Diri (APD): Dalam Manajemen Penanganan Covid-19. Jakarta: Kementerian Kesehatan Repulik Indonesia

Fajarsatu.com. 2020. Satu Pasien Covid-19 Meninggal, Rumah Sakit Harus Siapkan 20 APD dan Anggaran Hingga Rp 15 Juta. https://fajarsatu.com/2020/04/satupasien-covid-19-meninggal-rumah-sakit-harus-siapkan-20-apd-dan-anggaranhingga-rp-15-juta/

Gugus Tugas Percepatan Penanganan Covid-19. 2020. "Covid-19 di Indonesia: Update 25 Mei 202012.00 WIB. https://covid19.go.id/p/berita/infografis-covid19-25-Mei-2020

Handoyo, Rahmad. 2020. "Lindungi Tenaga Medis dari Covid-19, Anggota DPR Dorong Pemerintah Produksi APD”. http://www.dpr.go.id/berita/detail/id/28156/t/Lindungi+Tenaga+Medis+dari+Co vid-19\%2C+Anggota+DPR+ Dorong+Pemerintah+Produksi+APD 
Hidayat, Ali Akhmad Noor. 2020. "Pemerintah Prediksi Kebutuhan APD Medis 12 Juta Paket”. https://bisnis.tempo.co/read/1324773/pemerintah-prediksikebutuhan-apd-medis-12-juta-paket/full\&view=ok

Kasdi, Abdurrahman (2014). Peran Nadzir dalam Pengembangan Wakaf. Jurnal Zakat Dan Wakaf, 1(2), 1-20.

Musyfikah Ilyas. 2017. "Profesional Nazhir Wakaf dalam Pemberdayaan Ekonomi" Al-Qadau: Jurnal Peradilan dan Hukum Keluarga Islam, 4 (1): 71-94

Neneng Nurhalimah. 2020. "Efforts to Defend the Country Through Social Distancing and Lockdown to Overcome the COVID-19 plague". Salam; Jurnal Sosial dan Budaya Syar-I, 7 (3): 1-6 https://papers.ssrn.com/ sol3/papers.cfm?abstract_id=3576405

Nugraheny, Dian Erika. 2020. "Kemenkes: RS Perlu Patuhi 4 Pedoman Pemilihan APD untuk Tenaga Kesehatan", https://nasional.kompas.com/read/2020/04/09/ $\underline{11001831 / k e m e n k e s-r s-p e r l u-p a t u h i-4-p e d o m a n-p e m i l i h a n-a p d-u n t u k-t e n a g a-~}$ kesehatan.

Prasinanda, Risca Putri dan Tika Widiastuti. 2019. "Peran Nazhir dalam Mengelola Hasil Wakaf Uang pada Badan Wakaf Indonesia Jawa Timur". Jurnal Ekonomi Syariah Teori dan Terapan, 6 (12): 2553-67.

Puspaningtyas, Lida. 2020. "Fintech Syariah Bisa Ambil Peluang Social Crowdfunding”. https://republika.co.id/berita/q90wt3368/fintech-syariah-bisaambil-peluang-emsocial-crowdfunding-em

Rashid, Syed Khalid. (2018). Potential of Waqf in contemporary world. Journal of King Abdulaziz University, Islamic Economics, 31(2), 53-69.

Ridhoi, Muhammad Ahsan. 2020. "Ramai Penggalangan Donasi Corona, Ini Tip Agar Tak Salah Sasaran" https://katadata.co.id/berita/2020/03/23/ ramaipenggalangan-donasi-corona-ini-tip-agar-tak-salah-sasaran

Tiswarni. (2014). Peran Nazhir dalam Pemberdayaan Wakaf (Tinjauan Terhadap Strategi Pemberdayaan Wakaf Badan Wakaf Al-Qur'an dan Wakaf Center). Al'Adalah, 12(2), 409-426.

Sukmana, Raditya. (2019). Wakaf Era 4.0. Airlangga University Press.

. (2020). "Peluang dan Tantangan Penggunaan Blockchain dalam Perwakafan Nasional". dipresentasikan pada Forum Kajian Wakaf Seri 01 Tahun 2020, Pengelolaan Wakaf Berbasis Blockchain: Peluang dan Tantangan, Selasa, 21 April 2020, $10.00-12.00$ WIB.

Usman, R. (2009). Hukum Perwakafan di Indonesia. Sinar Grafika. 
Worldometer. 2020. “COVID-19 Coronavirus Pandemic by Country (Indonesia): Last updated: May 25, 2020, 23:48 GMT". https://www.worldometers.info/ coronavirus/country/indonesia/

Yohanes, David. 2020. "Perawatan PDP Virus Corona di RSUD dr Iskak Tulungagung Mencapai Rp 180 juta per Orang”. https://surabaya.tribunnews.com/2020/03/16/perawatan-pdp-virus-corona-dirsud-dr-iskak-tulungagung-mencapai-rp-180-juta-per-orang

Yunus, Nur Rohim dan Annissa Rezki. 2020. "Kebijakan Pemberlakuan Lock Down Sebagai Antisipasi Penyebaran Corona Virus Covid-19”. Salam; Jurnal Sosial dan Budaya Syar-I, 7 (3): 227-38. 